\title{
T. Б.Дмитриева
}

\section{ПРИНЦИПЫ ОРГАНИЗАЦИИ СОЦИАЛЬНО-ПСИХИАТРИЧЕСКОЙ ПОМОЩИ ДЕТЯМ В СОВРЕМЕННОЙ РОССИИ}

\author{
ГНЦ сощиальной и судебной психиатрии им. В.П. Сербского, г. Москва
}

Ц елью государственной социальной политики в отношении положения детей в Российской Федерации является преодоление негативных тенденций, обусловлен ных влиянием экономических и политических факторов, стабилизация ситуации по охране здоровья подрастающего поколения и создание реальных условий для закрепления положительной динамики в жизнеобеспечении детей. Реагирование общества и государства преимущественно на негативные последствия в детской среде неоптимально и малодейственно. Возникла необходимость в определении новых концептуальных подходов к охране здоровья и развития детей.

Всемирная декларация об обеспечении выживания, защиты и развития детей и Национальный план действия по ее осуществлению были подписаны Президентом Российской Федерации в январе 1992 г. Необходимо было определить основные приоритетные направления социальной политики в отношении детства. В настоящее время к ним относятся следующие напрвления: поддержка семьи как естественной и оптимальной среды для ребенка; поддержка детей, находящихся в особо трудных обстоятельствах (безнадзорность, криминальная среда, проживание в экологически грязных зонах, в регионах экономического застоя, военных действий); социальная и правовая защита интересов "социально уязвимых групп" детей с высоким риском нарушений возрастного психического, личностного развития, сопутствующих психических расстройств и отклонений поведения. Указанные проблемы являются и социально значимыми, и важными в клиническом аспекте, так как за ними стоят разнообразные патологические состояния и процессы, обусловленные негативными психологическими и материальными условиями жизни ребенка в современной России.

Патологические состояния, связанные с деструктивными социально-психическими воздействиями, нельзя изучать и понимать, а следовательно, и управлять ими на основе только биомедицинского, узко клинического подхода. Наша многолетняя работа с “социально уязвимыми" группами детей показыва- ет, что для диагностики, лечения, комплекс ной реабилитации детей этих групп необхо димы следуюшие предпосылки:

- сочетание клинических методов с соци. ально-психиатрическим подходом, включая разработку методических основ интеграции социально-психиатрическоro направления с клинической оценкой нарушений здоровья и развития детей;

- создание условий для организованного и методического обеспечения взаимодействия специалистов (педиатров, детских психиатров, подготовленных по психотерапии и социальной психиатрии, медицинских психологов, работников социальных служб) в целях охраны психического здоровья детей на уровне первичного звена - детской поликлиники по месту жительства, на уровне региональных детских консультативно-диагностических центров, на уровне программно-целевых разработок (целевая федеральная программа “Дети России", аналогичные программы, принятые в регионах в интересах детей).

Разработка основ социально-психиатрической помощи детям и их правовой защиты является одним из приоритетных направлений в Государственном научном центре социальной и судебной психиатрии им. В.П.Сербского. В первую очередь мы оказынаем социально-психиатрическую помощь детям и подросткам, находящимся в особо трудных жизненных обстоятельствах. К этой категории относятся сироты, оставшиеся без попечения родителей, безнадзорные дети с высоким риском криминальной активности, дети семей беженцев и вынужденных переселенцев, а также дети и подростки с противоправным поведением, содержащиеся в учреждениях реабилитационного типа Министерства образования, социальной зашиты и воспитательных колониях Министерства юстиции РФ.

Необходимо выделить следующие особенности оказания социально-психиатрической помощи в каждой из этих групп.

1. Социально-психиатрическая (консультативная, коррекционная, реабилитационная) помощь и правовая поддержка детям, оставшимся без попечения родителей, которые живут в 
детских домах и интернатах, а также передаются под опеку и усыновление.

Социальная динамика современной семьи характеризуется негативными тенденциями: дети, рожденные вне брака, составляют $25,3 \%$ от числа всех родившихся. Продолжается рост числа сирот и детей, оставшихся без попечения родителей: в 1996 г. их было 572,4 тыс. человек, в 1997 г. - 624,9 тыс., в 1998 г. -650 тыс., в 1999 - 674 тыс. Четвертая часть детейсирот лишена семейного окружения и живет в детских домах и интернатах. Социально-клинические исследования, проведенные в рамках президентской программы "Дети России" специалистами центра В.П.Сербского, показали, что у детей этой большой социальной группы наблюдается широкий спектр психогенно обусловленных патологических состояний:

- задержанное физическое и психическое созревание с нарушениями интеллекта, личностной незрелостью, депривационным развитием личности (до $62 \%$ случаев у детей, с раннего детства воспитывающихся в детских домах и интернатах)

- соматоформные или психосоматические расстройства, затяжные реакции на стресс $(43,7 \%$ у детей-сирот; $77,3 \%$ у детей из хронически конфликтных семей);

- отклонения поведения с патохарактерологическими реакциями $(22-23 \%)$.

Среди этих детей, которых можно характеризовать как "детей социального риска нарушений развития и поведения" при недостаточном использовании методов социально-психиатрической помоши отмечается неуклонный рост хронически болеющих детей с полиморфными, психосоматическими расстройствами.

Не менее тревожными являются данные о личностном, психопатологическом статусе женцин, отказывающихся от своих детей. Более чем в $1 / 3$ случаев у них отмечаются личностные расстройства с разнообразными аффективно-личностными реакциями, в $38 \%-$ сопутствуюшие аффективные расстройства в виде связанных с дистрессом депрессий с соматоформными расстройствами, в $13,8 \%$ задержка психического развития (чаще это женщины, которые сами воспитывались в учреждениях интернатного типа), в $11 \%$ хронические психические расстройства (шизофрения, эпилепсия). Социально-психологический анализ показывает, что более чем в $80 \%$ случаев отказа от ребенка ведущей причиной являются психогенно обусловленные, личностно окрашенные субдепрессивные нарушения, посттравматические стрессовые расстройства, связанные с распадом семьи.
Можно утверждать, что социально-психи атрическая помощь детям необходима в двух аспектах. Первый из них связан с идеями о значимости для ребенка надежной заботы ("good enough holding") со стороны эмоционально значимых лиц, которые принимают роль матери, обеспечивают социализацию и интеграцию ребенка. Ребенок, которым эмоционально пренебрегают, не может позитивно социализироваться: у него не формируется эмоционально насыщенный "первичный" опыт обшения, базовое чувство "доверия" Реабилитационная, психотерапевтически насыщенная среда интернатного учреждения должна функционировать как хорошо заботящаяся о ребенке мать и формировать ценности правильно организованной семейной жизни. Именно в обеспечении такой реабилитационной среды состоит вклад социально-психиатрической помощи.

Второй аспект связан с оказанием социально-психологической поддержки и при необходимости психотерапевтической помощи матерям, переживаюшим в периоде "кризисной беременности" тревожно-тоскливые депрессивные эпизоды.или более выраженные расстройства, которые, как правило, продолжают сохраняться и в послеродовом периоде. Этот аспект помощи имеет прямое отношение к профилактике отказов от ребенка, к снижению смертности детей до года от патологических состояний, связанных с недостаточным уходом за ребенком, от несчастных случаев и травм.

Можно утверждать, что во многих семьях в настояшее время затрудняется гармоничное развитие ребенка, возрастает риск психических и психосоматических расстройств, связанных со стрессом. У многих детей в ситуации семейного дистресса возникает чувство одиночества и эмоционального отчуждения, что ведет к фиксации психических и психосоматических нарушений.

2. Социальная и психиатрическая помошь детям, испытывающим школьную дизадаптацию.

Согласно данным государственной статистики по состоянию на 1 сентября 1999 г., в России не обучалось более 68 тыс. детей и подростков в возрасте от 7 до 15 лет. Из них более 40 тыс. $(59,8 \%)$ уклонялись от обучения, в том числе 14 тыс. детей покинули образовательные учреждения, не получив основного общего образования. В общеобразовательных школах наблюдается значительное число учащихся с астеническими, соматоформными и эмоционально-поведенческими расстройства- 
ми. У $25 \%$ детей на фоне астенизации отмечается задержка физического развития с уменьшением массы тела, снижением мышечной силы. Рекордное увеличение учебных нагрузок стало в последние годы характерной чертой школьного образования. Рост числа психосоматических, соматоформных расстройств и соматических заболеваний с хроническим течением у обучающихся в школах с повышенными нагрузками в 2,5 раза выше, чем среди учащихся массовых школ.

Специалистами центра им. В.П.Сербского получены данные о наличии у детей с трудностями обучения следующих патологических состояний:

- легкая умственная отсталость с поведенческими нарушениями (12\%);

- органические эмоционально-лабильные (астенические) и познавательные расстройства, включая нарушения школьных навыков $(18 \%)$;

- астенические нарушения и соматоформные расстройства (40\%);

- тревожные расстройства по типу “школьного невроза" (15\%);

- эмоционально-поведенческие расстройства, включая проблемы, связанные с формированием зависимости от психоактивных вешеств (21\%).

Следовательно, дети с проблемами развития, поведения и стойкой школьной дизадаптацией нуждаются в комплексной психолого-медико-педагогической поддержке Комплексная диагностика, коррекционная и реабилитационная помощь таким детям должны осушествляться на основе междисциллинарного и межведомственного взаимодействия. Сегодня первичным звеном в оказании такой помощи является школьная психологическая служба во взаимодействии с психолого-медико-педагогическими консультациями.

Методологическая база оказания такой комплексной социально-психологической и социально-реабилитационной помоши разработана слабо. Медицинских специалистов, работающих в этих учреждениях, катастрофически не хватает, несмотря на то что эти учреждения, относящиеся к Министерству образования, практически обслуживают детей с нарушениями возрастного психического, личностного развития и пограничными психическими расстройствами.

3. Социально-психиатрическая, психологическая и коррекционная помощь детям из семей беженцев и вынужденных переселенцев.

Согласно данным Федеральной миграционной службы по состоянию на 01.02.2000 г., в
Российской Федерации зарегистрирова 880,4 тыс. вынужденных переселенцев и 79,9 т беженцев, в том числе 271,8 тыс. детей. Из н на учете состоят 46,8 тыс. детей из многоде ных семей. Дети в этих семьях нуждаются в д полнительном питании, оздоровлении, в а ресной социально-психологической поддер ке. Наш опыт оказания комплексной мед ко-психологической, психотерапевтической реабилитационной помощи в Дагестане, Ста ропольском крае, Московской и Тверско областях в рамках Федеральной целевой прс граммы “Дети семей беженцев и вынужден ных переселенцев" показал, что при отсут ствии такой помощи у пострадавших дете длительно сохраняются посттравматически стрессовые расстройства с утратой интересо и навыков к обучению. Ведушими асоциаль ными формами нарушений становятся безнад зорность с высоким риском бродяжничества попрошайничества и совершения противо правных действий. Большую тревогу вызывает тот факт, что цети из семей беженшев н могут адаптироваться к обучению в обычной образовательной среде. При медицинском обеспечении детей-мигрантов, которое осушествляется территориальными лечебно-профилактическими учреждениями по месту пребывания детей, недостаточно разрабатываются вопросы охраны психического здоровья, слабо и неэффективно привлекаются для оказания комплексной помоши медицинские психологи, детские психиатры, специалисты, имеющие психотерапевтическую подготовку.

Указанные последствия стойкой семейной и школьной дизадаптации, отягощенные стрессовыми расстройствами, задержанным психическим развитием и эмоционально-поведенческими нарушениями, усугубляются влиянием на личностные ценности "социально уязвимых" детей и подростков криминальной субкультуры. Это оказывает определенное влияние на преступность несовершеннолетних, которые сегодня относятся к криминально активной группе населения. Согласно данным МВД, в огделениях внутренних дел в 1999 г. за совершение правонарушений на учет были поставлены 106 тыс. детей, в том числе до возраста 14 лет - 82 тыс., от 14 до 16 лет 24 тыс.

В настоящее время наблюдаются высокая криминальная активность детей, не достигших возраста уголовной ответственности, рост числа правонарушений, совершаемых девушками (от числа всех доставленных в ОВД несовершеннолетних за совершение преступлений девушки составляют $38,4 \%$ ), и высокая 
Динамика преступлений, совершенных подростками

\begin{tabular}{c|c|c|c|c|c|c}
\hline Годы & $\begin{array}{c}\text { Общее } \\
\text { число } \\
\text { (тыс.) }\end{array}$ & $\begin{array}{c}\text { Прирост, } \\
\%\end{array}$ & Девушки & $\begin{array}{c}\text { Прирост, } \\
\%\end{array}$ & $\begin{array}{c}\text { В нарко- } \\
\text { тическом } \\
\text { опьянении } \\
\text { (тыс.) }\end{array}$ & $\begin{array}{c}\text { Прирост, } \\
\%\end{array}$ \\
\hline 1997 & 162,0 & -15 & 12,9 & $-25,2$ & 1,32 & +17 \\
1998 & 165,3 & +2 & 12,9 & 0 & 1,32 & 0 \\
1999 & 183,5 & +11 & 15,1 & +17 & 1,03 & -22
\end{tabular}

распространенность нарушений возрастного психофизического развития у малолетних правонарушителей. В таблице приведены статистические сведения по линии МВД, характеризующие эти процессы

По данным центра им. В.П.Сербского, частота психической патологии несовершеннолетних правонарушителей в возрастной группе до 14 лет составляет $80,2 \%, 14-15$ лет - 57,7\%, 16-17 лет - 38,6\%. Психическое состояние этого контингента детей и подростков отягощено выраженными проблемами педагогической запущенности. В 1999 г. каждый третий подросток-правонарушитель имел лишь начальное образование. Это определяет необходимость разработки системы комплексной психолого-медико-педагогической помоши, причем в первую очередь по двум группам риска. Первая группа - это дети с беспризорностью и асоциальным поведением, поставленные на социально-профилактический учет, но не достигшие возраста уголовной ответственности, вторая - несовершеннолетние с противоправным и криминальным поведением, направленные по судебным определениям в специальные образовательные школы закрытого типа Министерства образования России и воспитательные колонии для несовершеннолетних Министерства юстиции России. Формы и методы комплексной психолого-медико-педагогической помощи и реабилитационной работы с этими группами несовершеннолетних разрабатываются в центре им. В.П.Сербского.

Выделенные особенности социализации детей в современном российском обществе сочетаются с динамикой эпидемиологических показателей. За короткий (10 лет) период произошел существенный сдвиг в психическом здоровье детско-подростковой популяции. Он характеризуется ростом заболеваемости психическими расстройствами среди детей в 1,5 раза, среди подростков в 1,3 раза, особенно ростом частоты психосоциально обусловлен- ных нарушений (реактивные состояния, соматоформные расстройства, аномалии личностного развития, специфические нарушения психологического развития), а также психических расстройств, связанных с ранними органическими поражениями головного мозга. В какой-то степени эти данные связаны со снижением качества здоровья беременных и ростом числа осложнений беременности, в родах и послеродовом периоде (в 1999 г. удельный вес нормальных родов составил по России только $31,1 \%$ ).

Еще одной "болевой точкой" современной России становится прогрессируюшее ухудшение наркологической ситуации. Продолжается снижение возраста приобшения несовершеннолетних к токсико-наркотическим веществам. Употребление детьми и молодежью психоактивных веществ превращается в серьезную социальную, педагогическую и медицинскую проблему. В учреждениях органов здравоохранения в связи с необходимостью оказания наркологической помоши зарегистрированы 29,8 тыс. детей и подростков, употребляющих наркотические средства и психотропные вещества, и 17,3 тыс. употребляющих сильнодействующие и одурманивающие вешества. За употребление наркотических средств в органы внутренних дел доставлено более 21 тыс. несовершеннолетних.

В этих условиях первичная антинаркотическая профилактическая помощь должна быть направлена, во-первых, в более младшую возрастную группу, а во-вторых, в школы и семьи. В настоящее время у большинства детей и подростков отсутствует превентивная психологическая защита, сдерживающая приобщение к психоактивным веществам. Специалисты центра им. В.П.Сербского совместно с НИИ наркологии МЗ РФ при консультативной поддержке Минздрава России разработали концепцию профилактики злоупотребления психоактивными веществами в образовательной среде. Она рассмотрена и принята 
на заседании правительственной комиссии по противодействию злоупотреблению наркотическими средствами и их незаконному обороту. Для обеспечения активной антинаркотической помощи детям и семье в эту профилактическую деятельность наряду со специалистами образования, социальной защиты должны включиться и специалисты педиатрической службы. Они раньше, чем все остальные специалисты, могут отметить ухудшение ситуации в семье, обратить внимание на появление первых признаков приобщения ребенка к употреблению наркотиков. Внедрение системы активной профилактики, организация раннего выявления случаев употребления наркотиков среди детей на уровне семьи и школы потребуют участия педиатрической службы в первичном предупреждении наркотизации детей и необходимости методического обеспечения такой деятельности педиатров.

Накопленный опыт оказания социальнопсихиатрической помощи социально уязвимым группам детей и подростков позволил разработать основы социально-психиатрического направления в детской психиатрии и апробировать методы социально-психиатрической помоши в учреждениях Министерства образования, Министерства труда и Министерства юстиции России. В целях совершенствования социально-психиатрической помощи детям в группах риска приказом Минздрава России (№ 148 от 05.05.2000 г.) на базе центра В.П.Сербского создан Организационно-методический центр Минздрава России по медико-социальной помощи несовершеннолетним с проблемами развития и поведения. Деятельность центра направлена на координацию научных исследований в Российской Федерации по оказанию социально-психиатрической помоши несовершеннолетним групп риска. В центре разрабатываются новые организационные формы и методы медико-социальной и лечебно-реабилитационной работы с детьми и подростками, имеюшими проблемы в развитии и поведении.

Целесообразно выделить определенные методические принципы социально-психиатрической помоши детям.

1. Социально-психиатрический подход как метод медико-социальной помощи должен быть ориентирован на оценку психического здоровья и возрастного развития детей из групп социального риска. Именно у такого контингента в силу остроты, тяжести и деструктивности социальных и психогенных в03действий наблюдается высокая частота психогенно обусловленных психических расстройств, нарушений развития и поведения.

2. Социально-психиатрический подход, наряду с оценкой психического здоровья, возрастного и личностного развития детей должен включать характеристику их психологического и социального функционирования и ориентироваться на широкий спектр психосоциально обусловленных расстройств от дизадаптивных реакций в рамках психического здоровья до клинически выраженных психических расстройств.

3. Социально-психиатрическая помощь (консультативная, лечебно-коррекционная, реабилитационная) должна быть максимально приближена к условиям проживания ребенка (родительская - приемная семья, детский дом, интернат) или к учреждению, где ребенку оказывается социально-реабилитационная помошь. В связи с этим оптимальной формой организации труда специалистов при внедрении социально-психиатрической помощи следует считать многопрофильный бригадный метод на основе междисциплинарного и межведомственного взаимодействия специалистов и учреждений различных ведомств с оказанием помощи проблемной семье и проблемному ребенку.

На настоящем этапе становления социально-психиатрического направления при оказании помощи детям и семье обсуждение выделенных принципов позволяет через социально-психиатрический подход объединить усилия специалистов по детству в комплексной, системной оценке возрастного психического и личностного развития "социально уязвимых" детей с высоким риском формирования патологии, а также обратить внимание на разработку методических основ привлечения педиатров как специалистов, наиболее приближенных к семье и детям, на проблематику охраны психического здоровья. Кроме того, необходимо внести дополнения в программы последипломного образования (врачей) специалистовпедиатров, детских психиатров, медицинских психологов по основам социально-психологической, социально-психиатрической помоши в детско-подростковой популяции и правовой поддержке детей. 